\title{
Is similar the distribution of Chironomidae (Diptera) and Oligochaeta (Annelida, Clitellata) in a river and a lateral fluvial area?
}

\author{
A distribuição de Chironomidae (Diptera) e Oligochaeta (Annelida, Clitellata) é \\ similar em um rio e área fluvial lateral?
}

\section{Daniela Aparecida Silveira Cesar ${ }^{1 *}$ and Raoul Henry ${ }^{1}$}

\author{
${ }^{1}$ Departamento de Zoologia, Instituto de Biociências, Universidade Estadual Paulista - UNESP, \\ Rua Prof. Dr. Antonio Celso Wagner Zanin, s/n, Distrito de Rubião Júnior, CEP 18618-689, \\ Botucatu, SP, Brazil \\ *e-mail: daniela_s.cesar@hotmail.com
}

Cite as: Cesar, D.A.S. and Henry, R. Is similar the distribution of Chironomidae (Diptera) and Oligochaeta (Annelida, Clitellata) in a river and a lateral fluvial area? Acta Limnologica Brasiliensia, 2017, vol. 29, e6.

Abstract: Numerous factors may affect the pattern of distribution of benthic fauna in a river mouth region and, among the macroinvertebrates, Chironomidae and Oligochaeta are the most abundant groups and most tolerant to environmental changes. Aim: The aim of this study was to evaluate the controlling factors of and a possible similarity between Chironomidae and Oligochaeta assemblies at two close sites, the mouth of the Guareí River into the Paranapanema River (São Paulo, Brazil) and its lateral fluvial area. Methods: Fauna samples were collected every three months during one year. Water physical and chemical variables and sediment variables were also determined in the same period. Results: Both assemblies presented low density variability over time in the lateral area due to sediment characteristics and environmental factors. Taxa Caladomyia, Parachironomus, Pristina sp., Pristina osborni, Bothrioneurum and Opistocysta funiculus were recorded at this site. The Guareí River presented both greater temporal and spatial variations, attributed mainly to a reduction in the water level. Greater organism abundance, especially of Chironomus and Tubificinae, was observed in the river. Conclusions: Dissimilarity in temporal and spatial distributions of Chironomidae and Oligochaeta was attributed to peculiar characteristics of the two study sites, a river channel and a lateral area. Reduction in the water level over the year was the main controlling factor of Chironomidae and Oligochaeta richness and density in the river. In the lateral area, the presence and abundance of certain taxa were determined by the nature of the sediment and water physical and chemical variables.

Keywords: mouth zone; water level; sediment; macroinvertebrates.

Resumo: Diversos fatores podem afetar o padrão de distribuição da fauna bentônica em regióes de desembocadura de rios e, entre os macroinvertebrados, Chironomidae e Oligochaeta são os grupos mais abundantes e tolerantes às alteraçóes ambientais. Objetivo: $\mathrm{O}$ objetivo deste estudo foi avaliar a possível similaridade e os fatores controladores entre as assembleias de Chironomidae e Oligochaeta em dois locais próximos, a zona de desembocadura do rio Guareí no rio Paranapanema (SP, Brasil) e sua área fluvial lateral. Métodos: As amostras de fauna foram coletadas a cada três meses durante um ano. As variáveis físico-químicas da água e sedimento também foram determinadas no mesmo período. Resultados: Ambas as assembleias apresentaram baixa variabilidade temporal nas densidades na área lateral devido às características do sedimento e dos fatores ambientais. Caladomyia, Parachironomus, Pristina sp., Pristina osborni, Bothrioneurum e Opistocysta funiculus foram registradas neste local. O rio 
Guareí apresentou maiores variações temporais e espaciais atribuídas principalmente a uma redução no nível da água. Elevada abundância de organismos, especialmente de Chironomus e Tubificinae, foram observadas no rio. Conclusóes: A dissimilaridade na distribuição temporal e espacial de Chironomidae e Oligochaeta foi atribuída às características peculiares dos dois locais de estudo, o canal do rio e a área lateral. A redução do nível de água ao longo do ano foi o principal fator controlador da riqueza e densidade de Chironomidae e Oligochaeta no rio. $\mathrm{Na}$ área lateral, a presença e a abundância de determinados taxa foram atribuídas à natureza do sedimento e às variáveis físicas e químicas da água.

Palavras-chave: zona de desembocadura; nível da água; sedimento; macroinvertebrados.

\section{Introduction}

Wetlands lateral to water courses are commonly observed in medium and large size basins. The ensemble formed by a river main channel and its secondary branches and lakes makes up a large ecologic unit, a floodplain (Neiff, 2003).

Floodplains are a complex habitat mosaic that interconnects aquatic and terrestrial environments along a lateral gradient (Ward \& Stanford, 1995). The connection between the river and the marginal lentic ecosystems is determined by variations in the hydrological level of the water course over the year. The hydrologic pulse is the main controlling factor of aquatic fauna composition, richness and abundance on floodplains (Junk et al., 1989; Martins \& Henry, 2004). Variation in the connectivity between floodplain environments is determined by flood pulse amplitude and frequency, which result in differences in potamophase (flood) and limnophase (isolation of lateral aquatic ecosystems) during the year (Neiff, 1997; Dawidek \& Ferencz, 2016). Pulse intensity determines variations in floodplain lake morphometric parameters dependent on the topography of the landscape where it is located (Ferencz \& Dawidek, 2016). Obolewski et al. (2015) demonstrated that the connectivity of the Lyna River (NE, Poland) to marginal oxbow lakes has a significant effect on the structure of lacustrine macroinvertebrates. In contrast, Montalto \& Paggi (2006) reported that variations in the water level, degree of disconnection and gradual desiccation of an area marginal to the Paraná River did not limit the distribution and abundance of Chironomidae.

Distinct floodplain aquatic phases may lead to variations in habitat (river, channel and lake) uniformity or heterogeneity. In the potamophase, habitat similarity results from the connectivity produced by the flood pulse (Thomaz et al., 2007; Zilli \& Marchese, 2011). In lateral environments during the isolation phase, habitat heterogeneity caused by the decrease in the water level results in singular biotic assemblies (Montalto \& Paggi, 2006; Mesa et al., 2012).
The mouth zones of rivers into reservoirs, called artificial wetlands, are generally made up of a set of aquatic environments apparently permanently connected to the rivers (Junk et al., 2014). The connection between marginal lacustrine environments and the mouth zone tributaries is maintained as a function of the water mass accumulated in their basins, expressed by the residence time (volume/flow), forming an extensive wet area. The large volume of water retained by dams, together with the system operation, is responsible for a strong attenuation of the tributaries' water pulses at the confluence with reservoirs (Henry, 2005) The alternation of two phases (potamophase and limnophase) in wetlands during the year is not a characteristic commonly observed at mouth sites (Henry et al., 2011). Aquatic areas marginal to rivers form an apparently uniform large set, given the association between both environments and the similarity between aquatic organism habitats.

A group of aquatic organisms especially important in fresh water ecosystems due to the role they play is benthic invertebrates. They participate in essential ecological processes, accelerating the decomposition of organic detritus, releasing nutrients through their feeding, excretion and sediment bioturbation. As predators, they control the density of their preys and are food sources for other organisms, such as fish (Covich et al., 1999).

Benthic macroinvertebrates are very sensitive to physical and chemical disturbances (Furse et al., 2006; Jesús-Crespo \& Ramírez, 2011), since they cause a reduction in the diversity and abundance of their assemblies and an increase in the dominance of species capable of tolerating adverse conditions (Smith \& Lamp, 2008; Jesús-Crespo \& Ramírez, 2011; Wang et al., 2012). Their distribution, occurrence and abundance greatly depend on the predominant characteristics of the environment. Their variability is generally attributed to abiotic factors, such as depth, temperature, food resources and mainly to substrate characteristics (Sanders, 1958; Gray, 1974; Sanseverino et al., 1998; Chapman et al., 2010). They are also sensitive to variations in the 
concentration of dissolved oxygen (Hirabayashi \& Hayashi, 1994).

Among macroinvertebrates, Oligochaeta are some of the most abundant groups, as they are present in almost all fresh water environments. They play an important role in the structuring of sediment (Drago et al., 2004; Marchese, 2009) and as a food source for other aquatic organisms (Reynoldson \& Rodriguez, 1999; Prygiel et al., 2000). They tolerate low levels of dissolved oxygen well (Verdonschot, 1989). Many Oligochaeta species are abundant at sites with high organic matter concentrations and they may replace other benthic macroinvertebrates less tolerant of these conditions (Schenková \& Helešic, 2006). Oligochaeta assemblies are influenced by habitat availability, organic content and substrate type (Ragonha et al., 2014).

Another macroinvertebrate group very important to the benthic community is the Chironomidae. This Diptera family has a large number of species, a highly variable density and very high diversity (Epler, 2001). The range of tolerance and sensitivity of Chironomidae larvae to organic pollution varies widely (Armitage, 1995). They may tolerate desiccation by making tubes or cocoons to preserve moisture when the sediment is exposed after a reduction in water level. They also may go into latency or produce eggs resistant to unfavorable environmental conditions (Montalto \& Paggi, 2006). Another peculiarity of Chironomidae is the possibility of some species survival in low oxygenation conditions due to the presence of hemoglobin, which allows the maintenance of aerobic metabolism until they go into latency under anoxia conditions (Hamburger et al., 1997). According to Sanseverino \& Nessimian (2001), different Chironomidae taxa occupy a large variety of habitats and they are preferably found in different systems (streams, rapid zones and large ponds, lakes and reservoirs) and distinct substrates (aquatic plants, detritus, rocks and sediment). Rosin \& Takeda (2007) reported that in the Paraná River's wetlands, the spatial variation of Chironomidae is associated with sediment type, organic matter content and the presence of aquatic macrophytes.

The mouth zone of the Paranapanema River into the Jurumirim reservoir, the site of this study, where an overbanking of the water from the river occurs during the high water phase and disconnection is observed between the aquatic environments during the drought phase, cannot be considered a wetland system (Henry, 2003). The connection between the river and the lakes is permanent, with the exception of short dry periods (Henry et al., 2011). As their connection is permanent, flood pulses do not occur with the intensity and frequency observed in flatlands. The lateral input of water resulting from the seasonal variation in the river water level modifies the depth of the flooded marginal areas; it increases during the rainy season and decreases during the dry season (Henry, 2003).

The continued connectivity between the river and the area lateral to the channel during the whole year in the mouth zone of tributaries into reservoirs apparently contributes to habitat homogeneity and similarity between biotic communities.

The aim of this study is to examine casual similarity in composition, richness and abundance of Chironomidae and Oligochaeta assemblies in the sediment in two areas near a tributary mouth during the year. Our hypothesis is that the river and the marginal area are homogeneous due to the association between the two environments. We expect to find: a) a similarity between ecological attributes of assemblies from the two sites, b) a temporal variability as a result of variations in the water level and environmental variables.

\section{Material and Methods}

\subsection{Study area and sampling frequency}

The study was conducted in the mouth region of the Guareí River into the Paranapanema River, in the state of São Paulo, Brazil (Figure 1). The site is located upstream from the Jurumirim Reservoir and forms a wet area lateral to the Guareí River channel, except in short dry periods. Over its course of $89 \mathrm{~km}$, the Guareí River receives a large input of nutrients from sewage from the cities of Guareí and Angatuba and farming activity in its drainage basin (Fulan et al., 2012)

Water, sediment and fauna were sampled every three months during a year (October 2013, January, April and July 2014) in two regions, the Guareí River mouth (four sites located longitudinally, numbered from 1 to 4 ) and in the lateral area (four sites, numbered from 5 to 8 ) (Figure 1).

\subsection{Water physical and chemical variables and sediment characteristics}

The following environmental variables were measured at each site and period of the year: a) water temperature, with a mercury thermometer, b) water $\mathrm{pH}$ and conductivity, with a Micronal Mod. $322 \mathrm{pHmeter}$ and a Hach Mod.2511 conductivimeter, respectively, c) water dissolved oxygen by the Winkler method, modified with the addition of azide (Golterman \& Clymo, 1969), d) sediment composition, by sieving 

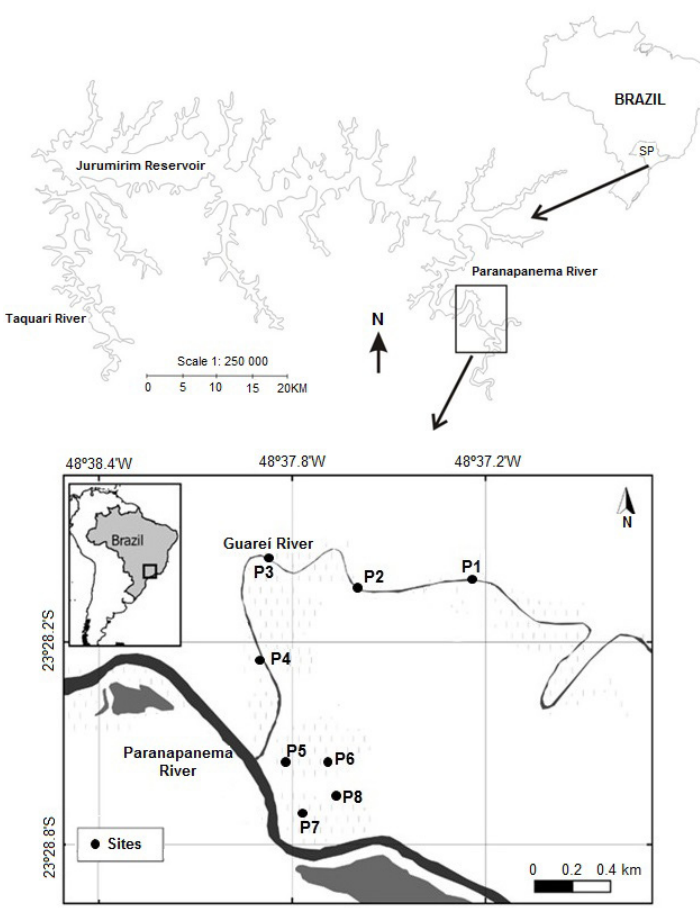

Figure 1. The study area in the mouth zone of the Guareí River into the Paranapanema River (São Paulo, Brazil) ( 1 to 4 , and 5 to 8 : sampling sites along the Guareí River and in the lateral area, respectively).

and particle size, assessed with the Wentworth scale (Suguio, 1973), e) organic matter content, determined after sediment combustion in an oven $\left(550^{\circ} \mathrm{C} / 1 \mathrm{~h}\right)$. Sampling site depth was determined by probing and water transparency, with a Secchi disk.

\subsection{Macroinvertebrates}

Sediment samples containing macroinvertebrates were collected with a Van Veen grab sampler (area of $0.064 \mathrm{~m}^{2}$ ), screened with a $250-\mu \mathrm{m}$ mesh and fixed with $4 \%$ formaldehyde. The organisms retained were examined by stereoscopic microscopy and preserved in 70\% alcohol. Taxa Chironomidae and Oligochaeta were identified based on Wiederholm (1983), Merrit \& Cummins (1984), Epler (2001) and Trivinho-Strixino (2011), Righi (1984), Brinkhurst \& Marchese (1989).

\subsection{Data analysis}

Variance analysis (ANOVA) was used to check for any significant variations in environmental and macroinvertebrate community variables between sampling months (Statistic 7, Statsoft 2009). Tukey's test was used to identify homogeneous groups after significant differences had been indicated by ANOVA. The Student t-test (Zar, 1999) was used to check for significant differences between sites (river and lateral plain) at a significance level of $\mathrm{p}<0.05$.

The spatial ordination of samples was determined by non-metric multidimentional scaling (NMDS). Bray-Curtis dissimilarity was calculated using packages Vegan and MASS for software R Cran Project (R Development Core Team, 2013). The correlations between species abundance and environmental variables were investigated by redundancy analysis (RDA) using the Vegan package for software R Cran Project (R Development Core Team, 2013).

\section{Results}

\subsection{Environmental variables}

Low rainfall in 2014 (total annual rainfall of $965.8 \mathrm{~mm}$ ), when compared to previous years, resulted in a reduction in the water level at the mouth of the Guareí River into the Paranapanema River and in the lateral area (Figure 2). The connection between the Guareí River and the lateral area was interrupted in May, as the water level was below the threshold of $563.60 \mathrm{~m}$ of connection/disconnection of Paranapanema River with the lateral areas, according to Henry (2005).

Water depth varied greatly between months and sampling sites (Figure 3A). The greatest depth was recorded on the Guareí River in October 2013, when a period of decrease in water level began (Figure 2B) and increase in transparency occurred (Figure 3B). A pronounced reduction in water level in April exposed the sediment at one of the sampling sites (8) and in July 2014, at three sites (6, 7 and 8), due to progressive desiccation (Figure 3A).

The concentration of dissolved oxygen was higher in October and lower in April (Figure 3C). The water electric conductivity of all sampling sites decreased in January in relation to October and increased after that (Figure 3D). No evident difference was observed in water $\mathrm{pH}$ values between sites and periods, expect for the Guareí River in July, where values were higher (Figure 3E). At sites closer to the mouth of the Guareí River into the Paranapanema River (3 and 4) and the lateral area, the organic matter content in the sediment was generally greater than $10 \%$ in all four sampling periods (Figure 3F).

In general, a predominance of silt + clay was recorded in the lateral area and fine sand on the Guareí River (Figure 4) in the four study periods. The amount of coarser sand particles was greater in April (Figure 4). Sediment granulometry was not determined at sites 6,7 and 8 in July due to a reduction in the flooded area lateral to the River channel. 

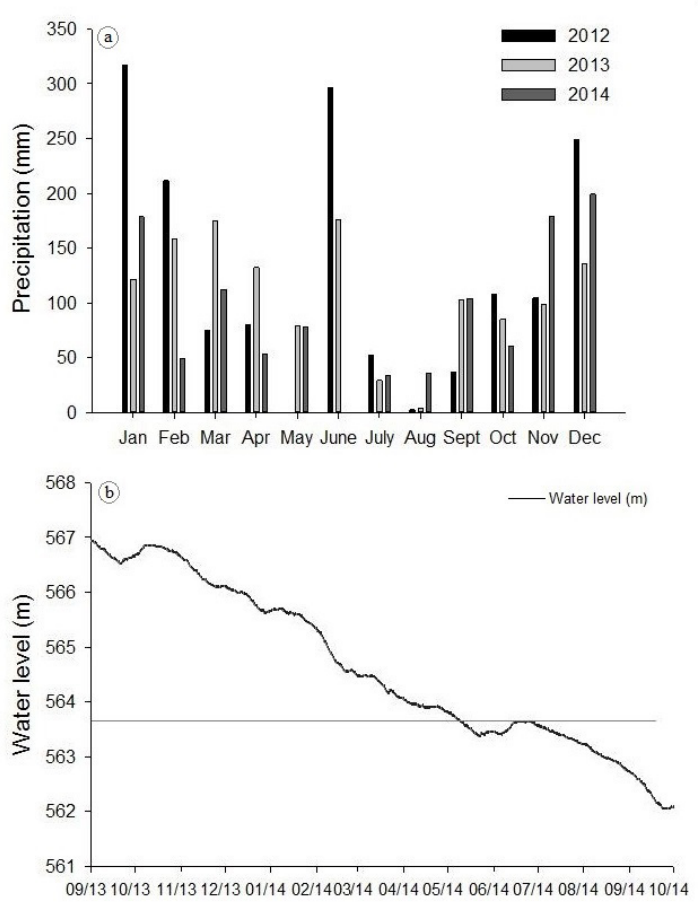

Figure 2. Monthly rainfall variation $(\mathrm{mm})$ for three years (a) and water level from September 2013 to October 2014 (b) and threshold of connection between the Paranapanema River and the lateral area.
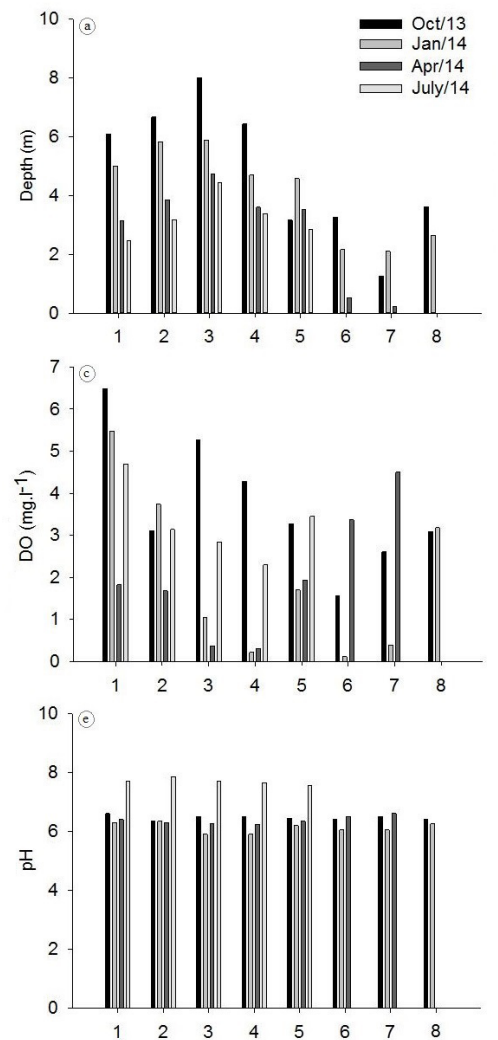

Significant temporal variations were detected for water depth, transparency, dissolved oxygen, conductivity, $\mathrm{pH}$ and temperature (Table 1). For sediment, significant differences between months were observed only for very coarse sand, and between sites, for fine sand (Table 1). Significant spatial differences were observed in water depth (decrease in lateral area) and temperature (high in the area lateral to the river channel) (Table 1). The sediment organic matter content did not differ significantly between sites; however, it was higher in the area lateral to the Guareí River. Water conductivity, $\mathrm{pH}$, depth and the percentage of fine sand were significantly higher on the Guareí River when compared to the lateral area (Table 1).

\subsection{Benthic macroinvertebrates}

A total of 24 taxa were sampled during the study. Chironomidae family were distributed in 13 taxa (Dicrotendipes, Chironomus, Parachironomus, Polypedilum, Xestochironomus, Caladomyia, Tanytarsus, Tanytarsus impar (Trivinho-Strixino \& Strixino), Tanytarsus obiriciae (Trivinho-Strixino \& Sonoda), Ablabesmyia, Coelotanypus, Monopelopia and Tanypus).

For the Oligochaeta class, were recorded 11 taxa (Dero (Aulophorus) lodeni (Brinkhurst, 1986), Nais

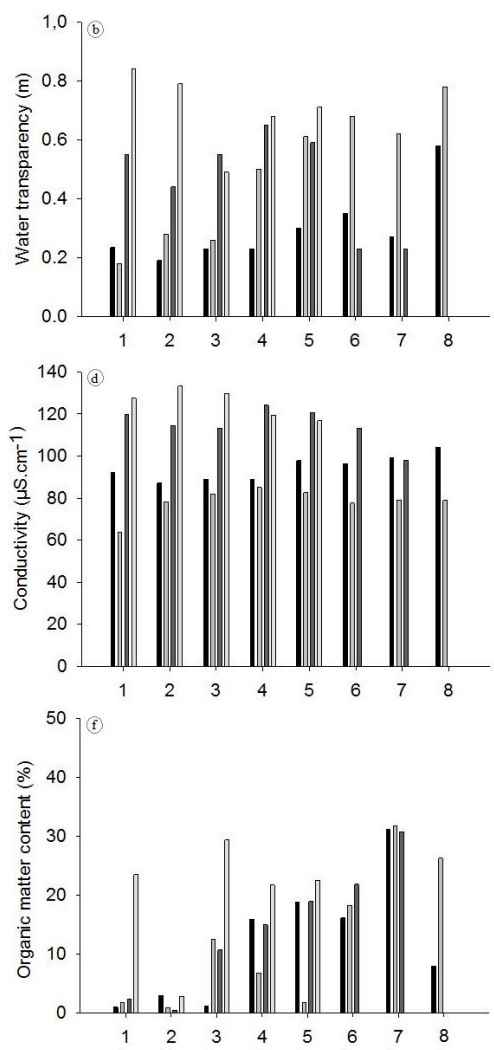

Figure 3. Temporal and spatial variation of depth (m) (a), water transparency (by Secchi disk) (b), dissolved oxygen (DO) (c), conductivity (d), $\mathrm{pH}(\mathrm{e})$ and organic matter in sediment (f) on the Guareí River (1-4) and the lateral area (5-8) in October 2013, January, April and July 2014. 
communis (Piguet, 1906), Nais variabilis (Piguet, 1906), Aulodrilus pigueti (Kowalewski, 1914), Limnodrilus hoffmeisteri (Claparede, 1862), Bothrioneurum, Branchiura sowerbyi (Beddard, 1892), Pristina sp., Pristina osborni (Walton, 1906), Opistocysta funiculus (Cordero, 1948) and immature Tubificinae).

In relation to the Chironomidae family, Chironomus, Tanypus and Polypedilum had the greatest densities
(Table 2). The density of Chironomus was the highest in the Guareí River in three of the four study periods. Tanypus predominated in the lateral area, except in July. Polypedilum was not recorded in either of the two sites in either October or January and presented the highest densities in the river in April and July. The densities of the other Chironomidae taxa were higher in the Guareí River.
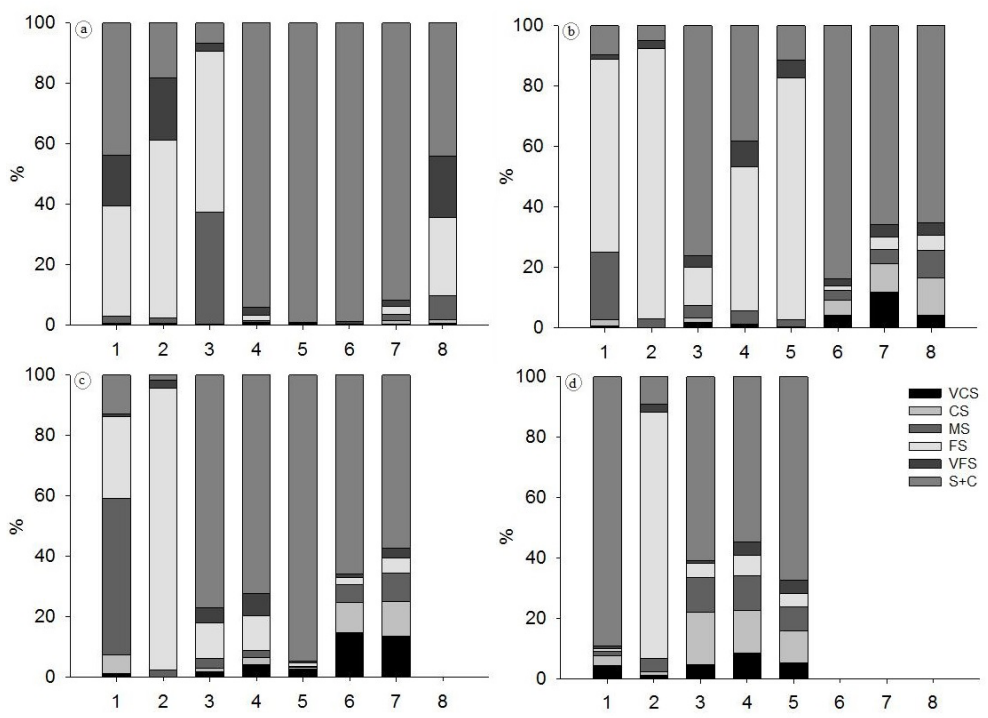

Figure 4. Sediment composition at the eight sampling sites (1-4: Guareí River; 5-8: lateral area) in October (2013) (a), January (b), April (c) and July (d) (2014) (VSC: very coarse sand; CS: coarse sand; MS: medium sand; FS: fine sand; VFS: very fine sand and $S+C$ : silt and clay).

Table 1. Differences in environmental variables and sediment composition determined by ANOVA ( $F$ and $\mathrm{p}$ ) and Student t-test ( $\mathrm{T}$ and $\mathrm{p}$ ) between sampling months (October, January, April and July) and sites along the Guarei River (1-4) and in the lateral area (5-8) and contrasts by Tukey test (significant differences in bold).

\begin{tabular}{|c|c|c|c|c|c|c|c|}
\hline $\begin{array}{l}\text { Environmental } \\
\text { variables }\end{array}$ & $\begin{array}{l}\mathrm{F} \text { and } \mathrm{T} \\
\text { values }\end{array}$ & $\mathbf{P}$ & $\begin{array}{c}\text { Tukey } \\
\text { contrasts }\end{array}$ & $\begin{array}{c}\text { Sediment } \\
\text { composition }\end{array}$ & $\begin{array}{l}F \text { and } T \\
\text { values }\end{array}$ & $\mathbf{P}$ & $\begin{array}{c}\text { Tukey } \\
\text { contrasts }\end{array}$ \\
\hline Depth & & & & Organic matter & & & \\
\hline Months & 3.23 & 0.03 & Oct>Jul & Months & 0.03 & 0.98 & \\
\hline Sites & 4.84 & 0.00 & & Sites & 1.78 & 0.08 & \\
\hline Secchi disk & & & & Very coarse sand & & & \\
\hline Months & 5.51 & 0.00 & Jul>Oct & Months & 3.63 & 0.02 & Apr $>$ Oct \\
\hline Sites & 0.93 & 0.35 & & Sites & 0.87 & 0.39 & \\
\hline Dissolved Oxygen & & & & Coarse sand & & & \\
\hline Months & 2.84 & 0.05 & Oct>Apr & Months & 4.29 & 0.01 & \\
\hline Sites & 1.66 & 0.10 & & Sites & 0.41 & 0.68 & \\
\hline Conductivity & & & & Medium sand & & & \\
\hline Months & 55.1 & 0.00 & Jul>Jan; Oct & Months & 0.37 & 0.77 & \\
\hline Sites & 2.31 & 0.02 & & Sites & 1.99 & 0.55 & \\
\hline $\mathrm{pH}$ & & & & Fine sand & & & \\
\hline Months & 161.0 & 0.00 & Jul>Jan & Months & 0.51 & 0.67 & \\
\hline Sites & 2.54 & 0.02 & & Sites & 4.00 & 0.00 & \\
\hline Water temperature & & & & Very fine sand & & & \\
\hline Months & 22.21 & 0.00 & Jan; Apr> Oct; Jul & Months & 1.01 & 0.40 & \\
\hline \multirow[t]{4}{*}{ Sites } & 2.01 & 0.05 & & Sites & 1.60 & 0.12 & \\
\hline & & & & Silt + clay & & & \\
\hline & & & & Months & 0.27 & 0.84 & \\
\hline & & & & Sites & 0.16 & 0.87 & \\
\hline
\end{tabular}


The Oligochaeta assembly was made up of three taxa with high densities (Table 2). Immature Tubificinae had the highest densities in October and July in the Guareí River and the lateral area in January and April. B. sowerbyi and A. pigueti were numerically more important in the river in all the study periods. The other Oligochaeta taxa also presented higher densities in the Guareí River.

Immature Tubificinae, $A$. piqueti. B. sowerbyi and Chironomus had significantly higher densities in the Guareí River (Table 3). In July, the densities of immature Tubificinae, Chironomus and Tanypus were significantly higher than in the other sampling periods (Table 3).
The dissociation between the study environments (river and lateral area) in all sampling periods and for the two organism groups studied was demonstrated by NMDS (Figure 5). Greater temporal and spatial variability was demonstrated in the Guareí River for assemblies of both Chironomidae and Oligochaeta (Figures $5 \mathrm{~A}$ and $\mathrm{B}$ ).

RDA explained 80 and $81 \%$ of the environmental data variability and the abundance of Chironomidae and Oligochaeta, respectively (Figures 6A and B).

The most abundant Chironomidae taxa (Chironomus, Tanypus and Polypedilum) were associated with the Guareí River, the site of the greatest transparency, dissolved oxygen, $\mathrm{pH}$, conductivity and fine sand

Table 2. Means and standard-deviations of the densities (ind. $\mathrm{m}^{-2}$ ) of some Chironomidae and Oligochaeta taxa in October 2013 and January, April, and July 2014 at sites in the Guareí River (R) and the lateral area (L).

\begin{tabular}{|c|c|c|c|c|c|}
\hline \multirow{2}{*}{$\begin{array}{c}\text { Taxa } \\
\text { Chironomidae }\end{array}$} & \multirow{2}{*}{ Sites } & \multicolumn{3}{|c|}{ Months } & \multirow[b]{2}{*}{ Jul } \\
\hline & & Oct & Jan & Apr & \\
\hline \multirow{2}{*}{ Chironomus } & $\mathrm{R}$ & $43.2 \pm 51.2$ & $11.5 \pm 17$ & $45.5 \pm 28.4$ & $371 \pm 179.0$ \\
\hline & L & $8 \pm 9.2$ & $3.7 \pm 4.7$ & $177 \pm 143.8$ & $24.75 \pm 49.5$ \\
\hline \multirow{2}{*}{ Tanypus } & $\mathrm{R}$ & $0 \pm 0$ & $1.25 \pm 2.5$ & $0 \pm 0$ & $71.75 \pm 89.8$ \\
\hline & L & $1.25 \pm 2.5$ & $1.25 \pm 2.5$ & $33.75 \pm 67.5$ & $15.75 \pm 31.5$ \\
\hline \multirow{2}{*}{ Polypedilum } & $\mathrm{R}$ & $0 \pm 0$ & $0 \pm 0$ & $13 \pm 15.5$ & $511.75 \pm 989$ \\
\hline & $\mathrm{L}$ & $0 \pm 0$ & $0 \pm 0$ & $1.25 \pm 2.5$ & $0 \pm 0$ \\
\hline \multirow{2}{*}{ Other taxa } & $\mathrm{R}$ & $12.7 \pm 1$ & $6.5 \pm 10$ & $5 \pm 7$ & $29.25 \pm 25.1$ \\
\hline & $\mathrm{L}$ & $0 \pm 0$ & $0 \pm 0$ & $1.25 \pm 2.5$ & $0 \pm 0$ \\
\hline Oligochaeta & Sites & Oct & Jan & Apr & Jul \\
\hline \multirow{2}{*}{ Immature $T$. } & $\mathrm{R}$ & $385.5 \pm 424.2$ & $21 \pm 29.7$ & $12 \pm 8$ & $538.2 \pm 538.9$ \\
\hline & $\mathrm{L}$ & $0 \pm 0$ & $35.25 \pm 70.5$ & $23.2 \pm 40.1$ & $34 \pm 68$ \\
\hline \multirow{2}{*}{ B. sowerbyi } & $\mathrm{R}$ & $78 \pm 132.2$ & $82 \pm 160.7$ & $82 \pm 137.4$ & $87.25 \pm 85.2$ \\
\hline & $\mathrm{L}$ & $26 \pm 52$ & $2.5 \pm 2.8$ & $2.5 \pm 2.8$ & $4 \pm 8$ \\
\hline \multirow{2}{*}{ A. pigueti } & $\mathrm{R}$ & $12.4 \pm 119.6$ & $8.4 \pm 143.3$ & $20.8 \pm 123.9$ & $23 \pm 80.3$ \\
\hline & $\mathrm{L}$ & $1.25 \pm 2.5$ & $4 \pm 8$ & $0 \pm 0$ & $1.25 \pm 2.5$ \\
\hline \multirow{2}{*}{ Other taxa } & $\mathrm{R}$ & $14 \pm 15.5$ & $1.25 \pm 2.5$ & $10.2 \pm 12.6$ & $58.2 \pm 90$ \\
\hline & $\mathrm{L}$ & $1.25 \pm 2.5$ & $0 \pm 0$ & $3.7 \pm 7.5$ & $1.2 \pm 2.5$ \\
\hline
\end{tabular}

Table 3. Differences in densities of some Oligochaeta and Chironomidae taxa determined by ANOVA (F and p) and Student t-test ( $\mathrm{T}$ and p) in October 2013, January, April and July 2014 in the Guareí River (R) and the lateral area (L) and contrasts by Tukey test (significant differences in bold).

\begin{tabular}{|c|c|c|c|}
\hline & $\mathrm{F}$ and $\mathrm{T}$ values & $\mathbf{P}$ & Tukey contrasts \\
\hline \multicolumn{4}{|c|}{ Immature Tubificinae } \\
\hline Months & 3.97 & 0.01 & Jul>Apr \\
\hline Sites & 5.01 & 0.00 & \\
\hline \multicolumn{4}{|c|}{ Aulodrilus pigueti } \\
\hline Months & 2.28 & 0.08 & \\
\hline Sites & 3.09 & 0.00 & \\
\hline \multicolumn{4}{|c|}{ Branchiura sowerbyi } \\
\hline Months & 1.53 & 0.22 & \\
\hline Sites & 2.61 & 0.01 & \\
\hline \multicolumn{4}{|l|}{ Chironomus } \\
\hline Months & 9.03 & 0.00 & Jul>Jan; Oct/Apr>Jan \\
\hline Sites & 2.39 & 0.02 & \\
\hline \multicolumn{4}{|l|}{ Tanypus } \\
\hline Months & 9.23 & 0.00 & Jul>Oct;Jan;Apr \\
\hline Sites & 0.15 & 0.69 & \\
\hline
\end{tabular}



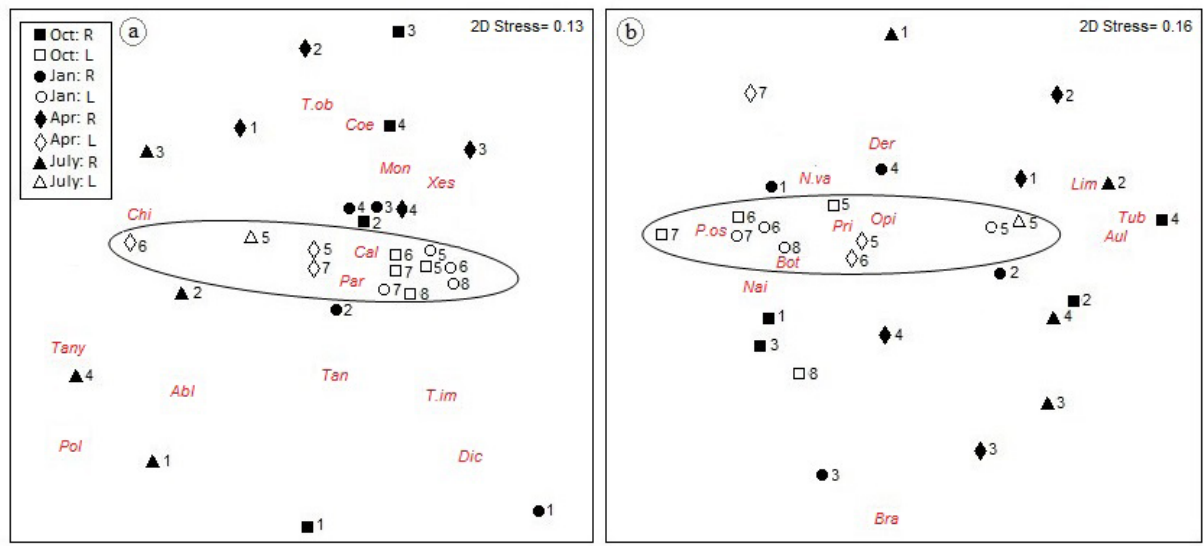

Figure 5. Non-metric multidimensional scaling (NMDS) based on Bray-Curtis similarity for Chironomidae (a) $(\mathrm{Cal}=$ Caladomyia, Par=Parachironomus, Tan=Tanytarsus, T.im=Tanytarsus impar, $\mathrm{Dic}=$ Dicrotendipes, $\mathrm{T} . \mathrm{b}=$ Tanytarsus obiriciae, $\mathrm{Coe}=$ Coelotanypus, Mon=Monopelopia, $\mathrm{Xes}=$ Xestochironomus, Chi=Chironomus, Tany $=$ Tanypus, $\mathrm{Pol}=$ Polypedilum, $\mathrm{Abla}=$ Ablabesmyia $)$ and Oligochaeta; (b) (Bra= Branchiura sowerbyi, P.os= Pristina osborni, Pristina sp., Opi $=$ Opistocysta funiculus, $\mathrm{Bot}=$ Bothrioneurum, $\mathrm{N} . \mathrm{va}=$ Nais variabilis, $\mathrm{Nai}=$ Nais communis, Der $=$ Dero (Aulophorus) lodeni, $\mathrm{Lim}=$ Limnodrilus hoffmeisteri, Aul= Aulodrilus pigueti, Tub= immature Tubificinae) in the Guareí River (R) (1-4) (black symbols) and the lateral area (L) (5-8) (white symbols) in October 2013 and January, April and July 2014.
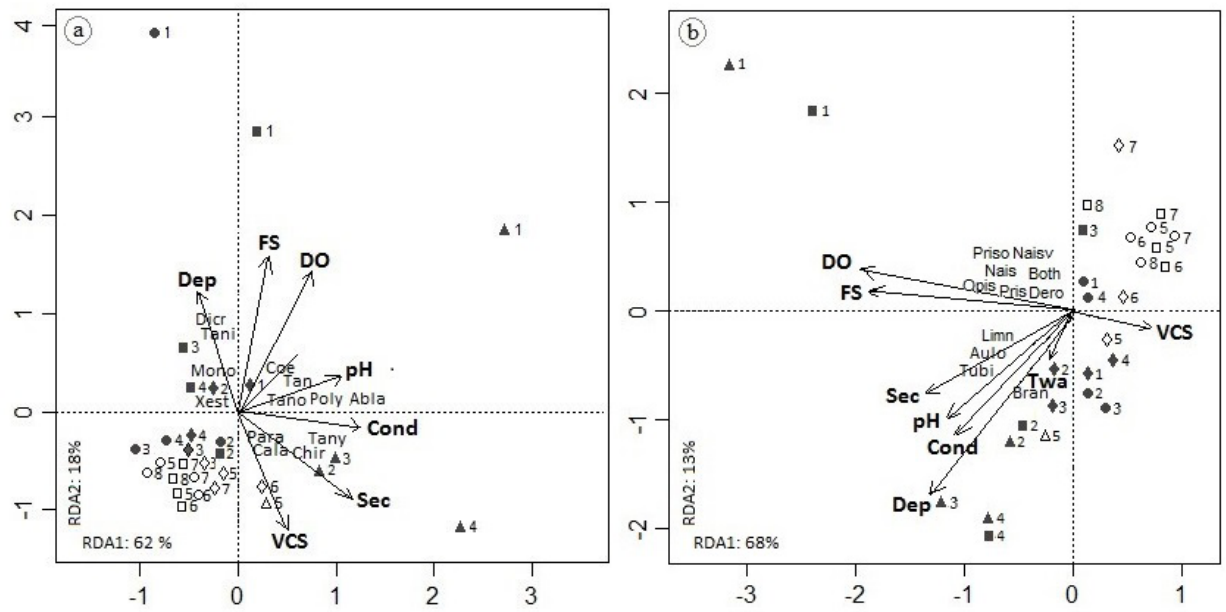

Figure 6. Redundancy analysis (RDA) for the abundance of Chironomidae (a) and Oligochaeta (b) and the environmental variables in the Guareí River (black symbols) (1-4) and lateral area (white symbols) (5-8) during the study period (see symbol key in Figure 5).

sediment (Figure 6A). In contrast, low abundance taxa (Dicrotendipes, Tanytarsus impar, Monopelopia and Xestochironomus) were associated with the Guareí River depth. In the lateral area, Parachironomus and Caladomyia were associated with very coarse sand.

A clear separation was observed for Oligochaeta between the lateral area and the Guareí River (Figure 6B). The lateral area sites were associated with very coarse sand sediment. Less abundant taxa (Dero (Aulophorus) lodeni, Nais communis, Nais variabilis, Bothrioneurum, Pristina sp., Pristina osborni and Opistocysta funiculus were associated with dissolved oxygen and fine sand upstream from the Guareí River (site 1) (Figure 6B). Limnodrilus hoffmeisteri, Aulodrilus pigueti, immature Tubificinae and Branchiura sowerbyi were associated with water depth, transparency, $\mathrm{pH}$, and conductivity (Figure 6B).

\section{Discussion}

Despite the short distance between the two study sites, our results demonstrated a lack of similarity in the distributions of Chironomidae and Oligochaeta when their assemblies in the Guareí River and the lateral area were compared.

Chironomidae taxa presented low spatial and temporal variability in the lateral area and a predominance of Caladomyia and Parachironomus. An increase in the percentage of very coarse sand in 
the sediment, together with a decrease in water level, seems to favor the presence of organisms from these two taxa at this site. Genus Parachironomus belongs to the collectors group (Coffman \& Ferrington, 1996; Henriques-Oliveira et al., 2003; Nessimian $\&$ Henriques-de-Oliveira, 2005) and its presence was favored by a large amount of organic matter resulting from the degradation of plant detritus in the lateral area and the substrate made up of coarse granulometry sediment. According to Butakka et al. (2014), Caladomyia larvae are collectors-filterers; they were found associated with coarse and very coarse sand, which may explain their presence in the area lateral to the Guareí River.

NMDS revealed a great spatial and temporal variability in the distribution of Chironomidae in the Guareí River channel. Tanytarsus sp., Tanytarsus impar and Dicrotendipes were associated with the upstream sampling site, which is characterized by the predominance of fine sand and a high dissolved oxygen content in the water. This Guareí River site is typically lotic, with turbulent water, which maintains small particles suspended. Tanytarsus obiriciae, Coelotanypus, Monopelopia and Xestochironomus were associated with the most downstream site of the Guareí River, close to the mouth zone into the Paranapanema River, a place with decreasing depths. According to Butakka et al. (2014), T. obiriciae are functional collectors-filterers organisms that live in the muddy bottom, while Coelotanypus individuals are shredders-herbivores organisms (Takeda et al., 2002). Xestochironomus is a taxon made up of organisms that mine underwater wood (Pinder, 1995) and are frequently found on sand banks (Sanseverino \& Nessimian, 2001). Representatives of the Monopelopia genus generally live in association with aquatic macrophytes in rivers, lakes and ponds (Trivinho-Strixino, 2011). In the mouth zone of the Guareí River, where these taxa were collected, there were large quantities of floating aquatic plants, with a predominance of Eichhornia azurea, Echinochloa polystachya and Salvinia auriculata, the detritus of which forms a sediment rich in organic matter.

The greatest densities of Chironomidae in July were observed during the period of a large concentration of dissolved oxygen. In that month, Chironomus, Tanypus, Ablabesmyia and Polypedilum were associated with the Guareí River segment with high water organic matter content, $\mathrm{pH}$ and conductivity. The reduction in the water volume in the Guareí River channel due to a decrease in the hydrological level and a presumed low current speed at the Paranapanema River mouth resulted in the sedimentation of larger particles. It also resulted in a greater concentration of organic acids and ions in water resulting from the degradation of vegetal detritus. The higher densities of these four Chironomidae taxa at this site and time of the year was due to the peculiar ecological characteristics of the Guareí River mouth zone. Rosin \& Takeda (2007) reported that organisms from genera Chironomus, Tanypus and Polypedilum are tolerant of a large variety of environmental conditions. According to Roback (1985), Ablabesmyia is frequently found in muddy sediment, such as observed at sites upstream from the Guareí River.

Similarly to that observed for Chironomidae, Oligochaeta organisms did not present great variability in spatial and temporal distribution in the area lateral to the Guareí River channel. Four taxa (Pristina sp., Pristina osborni, Bothrioneurum and Opistocysta funiculus) predominated in this area and were associated with two controlling factors (dissolved oxygen in water and fine sand). According to Rosa et al. (2015), Pristina species live at sites with varying particle sizes and water flow, while Bothrioneurum is commonly found in sandy habitats.

A great spatial and temporal variation was observed in the Guareí River for the distribution of Oligochaeta organisms. Branchiura predominated all through the year at a site close to the mouth of the Guareí River into the Paranapanema River and was associated with the water temperature. According to Raposeiro et al. (2009), this species is thermophilic and lives at sites deficient in oxygen, such as stagnant water, with low depth and renewal (Brinkhurst \& Jamieson, 1971). These characteristics are representative of the sites where they predominated. The other taxa (Dero (Aulophorus) lodeni, Nais communis, Nais variabilis, Aulodrilus pigueti, Limnodrilus hoffmeisteri and immature Tubificinae) were collected at two sites upstream on the Guareí River and at the site the closest to its mouth into the Paranapanema River. They were negatively associated with water depth, transparency, conductivity and $\mathrm{pH}$. Limnodrilus hoffmeisteri is found in a variety of habitats and ecological conditions (Nijboer et al., 2004) and, together with Aulodrilus pigueti, lives at sites with abundant organic matter (Marchese, 1987; Montanholi-Martins \& Takeda, 1998). These organisms present respiratory pigments (hemocyanin) that assist in breathing in environments with low concentrations of dissolved oxygen (Misenderino, 1995). Gorni \& Alves (2015) reported that in their study of water courses, Nais communis was associated with water conductivity and turbidity, such as observed for the Guareí River. 
Dero and immature Tubificinae are taxa commonly reported in environments with a high organic load (Martins et al., 2008), such as at the mouth of the Guareí River into the Paranapanema River.

Therefore, the heterogeneity between the environments was determined not only by the water physical chemical characteristics, but also by the nature of the site's sediment. Regarding granulometric composition, the quality of the sediment in rivers and lakes is one of the factors that most influences the distribution of benthic macroinvertebrates because many of them are restricted to certain types of substrates (Vitousek, 1990). In a study by Zilli et al. (2008), the factors sediment composition and presence of macrophytes and detritus were associated with habitat heterogeneity. A more diverse substrate offers a greater availability of habitats and microhabitats, foods and shelter from predators (Carvalho \& Uieda, 2004).

The variability of the composition of the sediment and the water physical chemical variables affected the distribution of organisms in the Guareí River and the lateral area over time. According to Montalto \& Paggi (2006) and Montalto et al. (2012), invertebrates that live in temporary wetlands are adapted to withstanding fluctuations in water level and desiccation conditions.

The differences in the distribution of species are due to changes in shelter availability and variety over time that affect the structure of the invertebrate fauna (Sanseverino et al., 1998). According to Martins et al. (2008), the variability of habitats over time determines the establishment and dominance of certain organisms, such as Chironomus and immature Tubificinae, which are tolerant of a large variety of environmental conditions and organic pollution. In the mouth zone of the Guareí River into the Paranapanema River, the difference in the distribution of Chironomus and immature Tubificinae in the water course and the lateral area reflects the heterogeneity of habitats lying within a short distance. In contrast, for macrophytes, distance does not have any association with assembly similarity in the high water period (Paiva et al., 2014). In the Jurumirim Reservoir, the distance between sampling sites is one of the relevant factors, besides habitat quality and the effect of damming on the heterogeneity of fish assembly composition and structure (Souza et al., 2017). The High (Takeda et al., 1997) and Middle Paraná (Drago et al., 2003) plain environments presented great differences in macroinvertebrate density in periods of disconnection from the river. Our data also differ from those reported for the Paraná River wetland, which has a great spatial homogeneity of limnological and zoobenthic assembly characteristics during the potamophase (Arenas-Ibarra et al., 2012).

Despite the spatial heterogeneity in the distribution of Chironomidae and Oligochaeta in the mouth zone of the tributaries and the lateral areas due to the variability of environmental characteristics, it is important to preserve the habitats in a microscale to maintain the biodiversity.

\section{Conclusion}

The dissimilar spatial and temporal distribution of Chironomidae and Oligochaeta assemblies was due to characteristics peculiar to the sites studied, the river channel and the lateral area. Higher richness and density of the two assemblies were observed in the river. The reduction in the water level during the year was the main controlling factor of Chironomidae and Oligochaeta richness and density in the river channel. In the lateral area, the nature of sediment and water physical chemical factors played a greater role in the presence of some taxa and their abundance.

\section{Acknowledgements}

The first author thanks Fundação de Amparo à Pesquisa do Estado de São Paulo (FAPESP) for a scientific initiation scholarship granted (Process No. 13/13299-4). The authors also acknowledge assistance from Hamilton Antônio Rodrigues in sampling, the invaluable suggestions from Gilmar Perbiche Neves, Jorge Laço Portinho and Carolina Vieira da Silva, and Laerte José da Silva for translating the paper into English.

\section{References}

ARENAS-IBARRA, J.A., TAKEDA, A.M. and FUJITA, D.S. O regime hidrológico do rio Ivinhema (Estado do Mato Grosso do Sul) e sua influência na assembléia zoobentônica. Acta Scientiarum: Biological Sciences, 2012, 34(1), 47-57.

ARMITAGE, P.D. The behaviour and ecology of adults. In: P.D. ARMITAGE, P.S. CRANSTON and L.C. PINDER, eds. The Chironomidae: the biology and ecology of nonbiting midges. London: Chapman and Hall, 1995, pp. 194-224.

BRINKHURST, R.O. and JAMIESON, B.G.M. Aquatic Oligochaeta of the World. Toronto: University of Toronto, 1971.

BRINKHURST, R.O. and MARCHESE, M.R. Guía para La identificación de oligoquetos acuáticos continentales de Sud y Centroamérica. Santa Fé: Asociación de Ciencias Naturales del Litoral, 1989. 
BUTAKKA, C.M.M., GRZYBKOWSKA, M.B., PINHA, G.D.C. and TAKEDA, A.M.D. Habitats and trophic relationships of Chironomidae insect larvae from the Sepotuba River basin, Pantanal of Mato Grosso, Brazil. Brazilian Journal of Biology = Revista Brasileira de Biologia, 2014, 74(2), 395-407. PMid:25166324. http://dx.doi.org/10.1590/15196984.26612 .

CARVALHO, E.M. and UIEDA, V.S. Colonização por macroinvertebrados bentônicos em substrato artificial e natural em um riacho de serra de Itatinga, São Paulo, Brasil. Revista Brasileira de Zoologia, 2004, 21(2), 287-293. http://dx.doi.org/10.1590/S010181752004000200021 .

CHAPMAN, M.G., TOLHURST, T.J., MURPHY, R. and UNDERWOOD, A.J. Complex and inconsistent patterns of variation in benthos, microalgae and sediment over multiple spatial scales. Marine Ecology Progress Series, 2010, 398, 33-47. http://dx.doi.org/10.3354/meps08328.

COFFMAN, W.P. and FERRINGTON, L.C. Chironomidae. In: K.W. MERRIT and R.W. CUMMINS, eds. An introduction of aquatic insects of North America. Dubuque: Kendall Hunt Publishing, 1996, pp. 635-754.

COVICH, A.P., PALMER, M.A. and CROWL, T.A. The role of benthic invertebrate species in freshwater ecosystems. Bioscience, 1999, 49(2), 119-127. http:// dx.doi.org/10.2307/1313537.

DAWIDEK, J. and FERENCZ, B. Historical changes of hydrological connectivity of selected polish floodplain lakes. River Research and Applications, 2016, 32(9), 1862-1871. http://dx.doi.org/10.1002/ rra.3035.

DRAGO, E.C., EZCURRA DE DRAGO, I., OLIVEROS, O. and PAIRA, A.R. Aquatic habitats, fishes and benthic assemblages of the Middle Paraná River. Amazoniana, 2003, 17, 291-341.

DRAGO, I.E., MARCHESE, M. and WANTZEN, M. Benthos of a large neotropical river: spatial patterns and species assemblage in the Lower Paraguay and its floodplains. Archiv für Hydrobiologie, 2004, 160(3), 347-374. http://dx.doi.org/10.1127/00039136/2004/0160-0347.

EPLER, J. Identification manual for the larval Chironomidae (Diptera) of North and South Carolina. Orlando: Departament of Enviromental and Natural Resources, 2001. 495 p.

FERENCZ, B. and DAWIDEK, J. Allometric relations between fluvial impulse and morphometric parameters of floodplain lakes. Hydrological Processes, 2016, 30, 534-542.

FULAN, J.A., HENRY, R. and DAVANSO, R. Anthropic action influence on macroinvertebrates distribution in Guareí River, São Paulo State - Brazil.
Estudos de Biologia, 2012, 34(82), 51-56. http:// dx.doi.org/10.7213/estud.biol.6123.

FURSE, M., HERING, D., MOOG, O., VERDONSCHOT, P., JOHNSON, R.K., BRABEC, K., GRITZALIS, K., BUFFAGNI, A., PINTO, P., FRIBERG, N., MURRAYBLIGH, J., KOKES, J., ALBER, R., USSEGLIOPOLATERA, P., HAASE, P., SWEETING, R., BIS, B., SZOSZKIEWICZ, K., SOSZKA, H., SPRINGE, G., SPORKA, F. and KRNO, I. The STAR project: context, objectives and approaches. Hydrobiologia, 2006, 566(1), 3-29. http://dx.doi. org/10.1007/s10750-006-0067-6.

GOLTERMAN, H.L. and CLYMO, R.S. Methods for chemical analysis of freshwaters. Oxford: Blackwell Scientific Publications, 1969, 174 p.

GORNI, G.R. and ALVES, R.G. Influência de variáveis ambientais sobre a comunidade de oligoquetos (Annelida: Clitellata) em um córrego neotropical. Biotemas, 2015, 28(1), 59-66. http://dx.doi. org/10.5007/2175-7925.2015v28n1p59.

GRAY, J.S. Animal-sediment relationships. Oceanography and Marine Biology: An Annual Review, 1974, 12, 223-262.

HAMBURGER, K., LINDERGAARD, C. and DALL, P.C. Metabolism and survival of benthic animals short of oxygen. In: K. SAND-JENSEN and O. PEDERSEN, eds. Freshwater biology: priorities and development in Danish research. Copenhagen: G. E. C. Gad Publs, 1997, pp. 183-185.

HENRIQUES-OLIVEIRA, A.L., NESSIMIAN, J.L. and DORVILLÉ, L.F.M. Feeding habits of chironomid larvae (Insecta: Diptera) from a stream in the Floresta da Tijuca, Rio de Janeiro, Brazil. Brazilian Journal of Biology = Revista Brasileira de Biologia, 2003, 63(2), 269-281. PMid:14509849. http:// dx.doi.org/10.1590/S1519-69842003000200012.

HENRY, R. Os ecótonos nas interfaces dos ecossistemas aquáticos: conceitos, tipos, processos e importância. Estudo de aplicação em lagoas marginais ao Rio Paranapanema na zona de sua desembocadura na Represa de Jurumirim. In: R. HENRY, ed. Ecótonos nas interfaces dos ecossistemas aquáticos. São Carlos: Rima Editora, 2003, pp. 1-28.

HENRY, R. The connectivity of the Paranapanema River with two lateral lakes in its mouth zone into the Jurumirim Reservoir. Acta Limnologica Brasiliensia, 2005, 17(1), 57-69.

HENRY, R., PANARELLI, E.A., CASANOVA, S.M.C., GRANADO, D.C., MORTARI, R.C. and ABRA, J. Plankton richness and abundance in several different hydrological situations in lakes lateral to a river: a case study in the mouth zone of a tributary into a tropical reservoir. Oecologia Australis, 2011, 15(3), 537-558. http://dx.doi.org/10.4257/oeco.2011.1503.08. 
HIRABAYASHI, K. and HAYASHI, H. Horizontal distribution of benthic macro invertebrates in Lake Kizaki. Japanese Journal of Limnology, 1994, 55(2), 105-114. http://dx.doi.org/10.3739/rikusui.55.105.

JESÚS-CRESPO, R. and RAMÍREZ, A. Effects of urbanization on stream physicochemistry and macroinvertebrate assemblages in a tropical urban watershed in Puerto Rico. Journal of the North American Benthological Society, 2011, 30(3), 739-750. http://dx.doi.org/10.1899/10-081.1.

JUNK, W.J., BAYLEY, P.B. and SPARKS, R.E. The flood pulse concept in river floodplain systems. Canadian Special Publication of Fisheries and Aquatic Sciences, 1989, 106(1), 110-127.

JUNK, W.J., PIEDADE, M.T.F., LOURIVAL, R., WITTMANN, F., KANDUS, P., LACERDA, L.D., BOZELLI, R.L., ESTEVES, F.A., NUNES DA CUNHA, C., MALTCHIK, L., SCHONGART, J., SCHAEFFER-NOVELLI, Y. and AGOSTINHO, A.A. Brazilian wetlands: their definition, delineation, and classification for research, sustainable management, and protection. Aquatic Conservation: Marine and Freshwater Ecosystems, 2014, 24(1), 5-22. http://dx.doi.org/10.1002/aqc.2386.

MARCHESE, M. Annelida, Oligochaeta. In: E. DOMÍNGUEZ and H. R. FERNÁNDEZ, eds. Macroinvertebrados sudamericanos: sistemática y biología. Tucumán: Fundación Miguel Lillo, 2009, pp. 550-565.

MARCHESE, M.R. The ecology of some benthic Oligochaeta from the Paraná River, Argentina. Hydrobiologia, 1987, 155(1), 209-214. http://dx.doi. org/10.1007/BF00025653.

MARTINS, G.M. and HENRY, R. Composição e abundância do zooplâncton em três lagoas laterais ao Rio Paranapanema na zona de sua desembocadura na represa de Jurumirim (São Paulo). In: S. CHELAPPA and J.Z.O. PASSAVANTE, eds. Ecologia aquática tropical. Natal: ServGraf, 2004, pp. 53-72.

MARTINS, R.T., STEPHAN, N.N.C. and ALVES, R.G. Tubificidae (Annelida: Oligochaeta) as an indicator of water quality in an urban stream in southeast Brazil. Acta Limnologica Brasiliensia, 2008, 20(3), 221-226.

MERRIT, R. and CUMMINS, K. An introduction to the aquatic insects of North America. 2 nd ed. Kendall: Hunt Publishing, 1984.

MESA, L.M., MARCHESE, M.R., MONTALTO, L. and ZILLI, F.L. Bidirectional exchanges of benthic invertebrates in a large river-floodplain system (Parana' River, Argentina). International Journal of Limnology, 2012, 48(4), 425-436. http://dx.doi. org/10.1051/limn/2012030.

MISENDERINO, M.L. Composición y distribuición del macrozoobentos de um sistema lótico andinopatagonico. Ecologia Austral, 1995, 5(2), 133-142.
MONTALTO, L. and PAGGI, A.C. Diversity of chironomid larvae in a marginal fluvial wetland of the Middle Paraná river floodplain, Argentina. International Journal of Limnology, 2006, 42(4), 289-300. http://dx.doi.org/10.1051/limn/2006029.

MONTALTO, L., CAPELLO, S. and PAGGI, A.C. First record and ecological features of Goeldichironomus petiolicola (Diptera: Chironomidae) mining Eichhornia crassipes in the Middle Paraná River floodplain, Argentina. Revista de la Sociedad Entomológica Argentina, 2012, 71(1-2), 137-144.

MONTANHOLI-MARTINS, M.C. and TAKEDA, A.M. Communities of benthic oligochaetes in relation to sediment structure in the upper Paraná River, Brazil. Studies on Neotropical Fauna and Environment, 1998, 34(3), 52-58. http://dx.doi. org/10.1076/snfe.34.3.52.8899.

NEIFF, J.J. El regimen de pulsos en rios y grandes humedales de Sudamerica. In A.I. MALVÁREZ, ed. Tópicos sobre humedales subtropicales y templados de Sudamerica. Montevidéu: MAB-UNESCO, 1997, pp. 97-146.

NEIFF, J.J. Planícies de inundação são ecótonos? In R. HENRY, ed. Ecótonos nas interfaces dos ecossistemas aquáticos. São Carlos: Rima, 2003, pp. 29-45.

NESSIMIAN, J.L. and HENRIQUES-DE-OLIVEIRA, A.L. Colonização do "litter" de Eleocharis sellowiana kunth. (Cyperaceae) por larvas de Chironomidae (Diptera) em um brejo no litoral do Estado do Rio de Janeiro. Entomologia y Vectores, 2005, 12(2), 159-172.

NIJBOER, R.C., WETZEL, M.J. andVERDONSCHOT, P.F.M. Diversidade and distribution of Tubificidae, Naididae, and Lumbriculidae (Annelida: Oligochaeta) in the Netherlands: an evaluation of twenty years of monitoring data. Hydrobiologia, 2004, 520(1-3), 127-141. http://dx.doi.org/10.1023/ B:HYDR.0000027732.88238.61.

OBOLEWSKI, K., GLIŃSKA-LEWCZUK, K. and STRZELCZAK, A. Does hydrological connectivity determine the benthic macroinvertebrate structure in oxbow lakes? Ecohydrology, 2015, 8(8), 1488-1502. http://dx.doi.org/10.1002/eco.1599.

PAIVA, J.R.A., MATIAS, L.Q., MARTINS, F.R. and BECKER, $H$. Does distance between aquatic plant assemblages matter in defining similarity between them during high water-level periods? Lakes and Reservoirs: Research and Management, 2014, 19(1), 37-45. http://dx.doi.org/10.1111/lre.12051.

PINDER, L.C.V. The habitats of chironomid larvae. In: P. ARMITAGE, P.S. CRANSTON and L.C.V. PINDER, eds. The Chironomidae: the biology and ecology of non-biting midges. London: Chapman and Hall, 1995, pp. 107-135.

PRYGIEL, J., ROSSO-DARMET, A., LAFONT, M., LESNIAK, C., DURBEC, A. and OUDDANE, B. Use of oligochaete communities for assessment of 
ecotoxicological risk in fine sediment of rivers and canals of the Artois-Picardie water basin (France). Hydrobiologia, 2000, 410, 25-35. http://dx.doi. org/10.1023/A:1003799224961.

$\mathrm{R}$ Development Core Team. $R$ : a language and environment for statistical computing [online]. Vienna: R Foundation for Statistical Computing, 2013 [viewed 3 Feb. 2017]. Available from: http:// www.R-project.org

RAGONHA, F.H., PINHA, G.D., PETSCH, D.K., MANSUR, M.C.D. and TAKEDA, A.M. First records of Freshwater Bivalves of Ilha Grande National Park, Paraná, Brazil. Iheringia: Série Zoologia, 2014, 104(1), 14-20. http://dx.doi. org/10.1590/1678-4766201410411420.

RAPOSEIRO, P.M., RAMOS, J.C. and COSTA, A.C. First record of Branchiura sowerbyi Beddard, 1892 (Oligochaeta: Tubificidae) in Azores. Aquatic Invasions, 2009, 4(3), 487-490. http://dx.doi. org/10.3391/ai.2009.4.3.8.

REYNOLDSON, T.B. and RODRIGUEZ, P. Field methods and interpretation for sediment bioassessment. In: A. MUDROCH, J.M. AZCUE and P. MUDROCH, eds. Manual of bioassessment of aquatic sediment quality. Boca Raton: Lewis Publishers, 1999, pp. 135-175.

RIGHI, G. Manual de identificação de invertebrados límnicos do Brasil. Brasília: Coordenação Editorial CNPq, 1984.

ROBACK, S.S. The immature Chironomids of the eastern United States. VI. Pentaneurini-genus Ablabesmyia. Proceedings. Academy of Natural Sciences of Philadelphia, 1985, 137(2), 153-212.

ROSA, B.F.J.V., MARTINS, R.T. and ALVES, R.G. Distribution of oligochaetes in a stream in the Atlantic Forest in southeastern Brazil. Brazilian Journal of Biology = Revista Brasileira de Biologia, 2015, 75(1), 1-7. PMid:25945614. http://dx.doi. org/10.1590/1519-6984.02313.

ROSIN, G.C. and TAKEDA, A.M. Larvas de Chironomidae (Diptera) da planície de inundação do alto rio Paraná: distribuição e composição em diferentes ambientes e períodos hidrológicos. Acta Scientiarum. Biological Sciences, 2007, 29, 57-63.

SANDERS, H.L. Benthic studies in Buzzards Bay. I. Animal sediment relationships. Limnology and Oceanography, 1958, 3(3), 245-258. http://dx.doi. org/10.4319/lo.1958.3.3.0245.

SANSEVERINO, A.M. and NESSIMIAN, J.L. Hábitats de larvas de Chironomidae (Insecta: Diptera) em riachos de Mata Atlântica no Estado do Rio de Janeiro. Acta Limnologica Brasiliensia, 2001, 13, 29-38.

SANSEVERINO, A.M., NESSIMIAN, J.L. and OLIVEIRA, A.L.H. A fauna de Chironomidae (Diptera) em diferentes biótopos aquáticos na Serra do Subaio (Teresópolis, RJ). In: J. L. NESSIMIAN and A. L. CARVALHO, eds. Ecologia de insetos aquáticos. Rio de Janeiro: Oecologia Brasiliensis, 1998, pp. 253-263. vol. 5.

SCHENKOVÁ, J. and HELEŠIC, J. Habitat preferences of aquatic Oligochaeta (Annelida) in the Rokttná River, Czech Republic- a small highland stream. Hydrobiologia, 2006, 564(1), 117-126. http://dx.doi. org/10.1007/s10750-005-1713-0.

SMITH, R.F. and LAMP, W.O. Comparison of insect communities between adjacent headwater and mainstem streams in urban and rural watersheds. Journal of the North American Benthological Society, 2008, 27(1), 161-175. http://dx.doi.org/10.1899/07-071.1.

SOUZA, J.Q., LIMA, F.P., NOBILE, A.B., SOUZA, D.F., SOUTO, A.C., PAES, J.V.K. and BRANDÃO, H. Composição e estrutura da ictiofauna. In: R. J. SILVA, ed. Integridade ambiental da Represa de Jurumirim: ictiofauna e relaçóes ecológicas. Ed. Unesp, 2017, pp. 55-78.

STATSOFT. Statistica (data analysis software system). version 6 [online]. Tulsa: Statsoft Inc., 2009 [viewed 3 Feb. 2017]. Available from: www.statsoft.com

SUGUIO, K. Introdução à sedimentologia. São Paulo: EDUSP, 1973, $317 \mathrm{p}$.

TAKEDA, A.M., LANSAC-TÔHA, F.A. and AGOSTINHO, A.A. Estudos ecológicos de longa duração: reservatório de Itaipu e Planície Alagável do Alto Rio Paraná. Cadernos da Biodiversidade, 2002, 3(2), 51-63.

TAKEDA, A.M., SHIMIZU, G.Y. and HIGUTI, J. Variaçóes espaço-temporais da comunidade zoobêntica. In: A.E.A.M. VAZZOLER, A.A. AGOSTINHO and N.S. HAHN, eds. Planicie de inundação do Alto Rio Paraná. Maringá: EDUEM, 1997, pp. 157-177.

THOMAZ, S.M., BINI, L.M. and BOZELLI, R.L. Floods increase similarity among aquatic habitats in river-floodplain systems. Hydrobiologia, 2007, 1(1), 1-13. http://dx.doi.org/10.1007/s10750-006$0285-\mathrm{y}$.

TRIVINHO-STRIXINO, S. Larvas de Chironomidae: guia de identificação. São Carlos: Laboratório de Entomologia Aquática, Departamento de Hidrobiologia, UFSCar, 2011.

VERDONSCHOT, P.F.M. The role of oligochaetes in the management of waters. Hydrobiologia, 1989, 180(1), 213-227. http://dx.doi.org/10.1007/ BF00027554.

VITOUSEK, P.M. Biological invasions and ecosystem process towards an integration of biology and ecosystem studies. Oikos, 1990, 57(1), 7-13. http:// dx.doi.org/10.2307/3565731.

WANG, B., LIU, D., LIU, S., ZHANG, Y., LU, D. and WANG, L. Impacts of urbanization on stream habitats and macroinvertebrate communities in the 
tributaries of Qiangtang River, China. Hydrobiologia, 2012, 680(1), 39-51. http://dx.doi.org/10.1007/ s10750-011-0899-6.

WARD, J.V. and STANFORD, J.A. Ecological connectivity in alluvial river ecosystems and its disruption by flow regulation. Regulated Rivers: Research and Management, 1995, 11(1), 105-119. http://dx.doi.org/10.1002/rrr.3450110109.

WIEDERHOLM, T. Chironomidae of the Holartic Keys and diagnoses (Part 1 -Larvae). Entomologica Scandinavica Supplement, 1983, 19, 1-457.

ZAR, J.H. Biostatistical analysis. 4th ed. Upper Saddle River: Prentice Hall, 1999.
ZILLI, F.L. and MARCHESE, M.R. Patterns in macroinvertebrate assemblages at different spatial scales. Implications of hydrological connectivity in a large floodplain river. Hydrobiologia, 2011, 663(1), 245257. http://dx.doi.org/10.1007/s10750-010-0576-1.

ZILli, F.L., MONTALTO, L., PAGGI, A. and MERCHESE, C. Biometry and life cycle of Chironomus calligraphus Goeldi 1905 (Diptera, Chironomidae) in laboratory conditions. Asociacion Interciencia, 2008, 33(10), 767-770.

Received: 03 February 2017 Accepted: 31 March 2017 